\title{
REG3A Gene
}

National Cancer Institute

\section{Source}

National Cancer Institute. REG3A Gene. NCI Thesaurus. Code C105382.

This gene may be involved in pancreatic cell proliferation and differentiation. 